\title{
Chylomicronemia Syndrome in Pregnancy: a Case Report of an Acute Necrotizing Pancreatitis
}

\author{
Chylomikronämie-Syndrom in der Schwangerschaft: \\ Ein Fallbericht einer akuten nekrotisierenden Pankreatitis
}

Authors

Affiliation
D. Bolla, V. Schyrba, G. Drack, A. Schöning, A. Stage, R. Hornung

Gynäkologie und Geburtshilfe, Kantonsspital St. Gallen, St. Gallen, Switzerland

Key words
O delivery
obstetrics
- metabolic defects
Schlüsselwörrter
- Geburt
- Geburtshilfe
- Stoffwechselprobleme

received $\quad 8.5 .2012$

revised 23.7.2012

accepted $\quad 7.8 .2012$

Bibliography

Dol http://dx.doi.org/

$10.1055 / \mathrm{s}-0032-1315295$

Geburtsh Frauenheilk 2012; 72 :

853-855 @ Georg Thieme

Verlag KG Stuttgart · New York . ISSN 0016-5751

\section{Correspondence \\ Dr. Daniele Bolla}

Kantonsspital St. Gallen

Gynäkologie und Geburtshilfe

Rorschacher Strasse 95

9007 St. Gallen

Switzerland

daniele.bolla@kssg.ch

\section{Abstract}

$\nabla$

Introduction: Chylomicronemia syndrome (CS) is a rare disorder characterized by a high level of triglycerides in plasma. We present a case of a pregnant woman with a severe acute pancreatitis (AP) affected by a CS.

Case: A 38-year-old gravida 2, para 0 with an uneventful course of pregnancy was referred with an AP at 37 0/7 weeks of gestation. This diagnosis was made from a nearby hospital where the chemical analysis showed elevated pancreatic enzymes with significant hypertriglyceridemia. Because of a pathological fetal heart tracing a caesarean delivery was performed. The APGAR score of the female newborn was $5 / 8 / 8$ at 1,5 and 10 minutes, respectively. The $\mathrm{pH}$ from the umbilical cord were 7.26 (artery) and 7.59 (vein). Once transferred to our intensive care unit a computer tomography scan confirmed an onset of a necrotizing AP. A conservative treatment was tried without success. For this reason a surgical debridement of the infected and necrosic parts was performed. After a long hospitalisation the patient could be dismissed after 2.5 months in good general condition.

Discussion: Lipid profile changes in normal pregnancy are characterized by an elevation of total plasma cholesterol and triglyceride levels. This is normally caused by an increased liver synthesis of triglycerides in response to elevated estrogen levels. When a CS is diagnosed the main goal is to maintain fasting triglyceride levels at less than $500 \mathrm{mg} / \mathrm{dL}$ to reduce the risk for AP.

Conclusion: Practitioners have an important role in evaluating chylomicronemic patients and implementing therapeutic lifestyle and pharmaceutic interventions aimed to reduce the risk for AP.

\section{Zusammenfassung \\ $\nabla$}

Einführung: Das Chylomikronämie-Syndrom (CS) ist eine seltene Erkrankung charakterisiert durch eine Triglyceriderhöhung. Eine akute und ggf. lebensbedrohliche Komplikation davon ist die akute Pankreatitis (AP). Wir berichten über den Fall einer AP bei einer Schwangeren mit einem CS. Fallbericht: Eine 38-jährige Gravida 2, Para 0 in der 37 0/7 SSW mit einem bis dahin unauffälligen Schwangerschaftsverlauf wurde mit einer AP ins Kantonsspital St. Gallen verlegt. Die Diagnose stellte ein kleineres Spital durch die Laboranalyse: erhöhte Pankreasenzyme mit einer signifikanten Hypertriglyceridämie. Aufgrund eines pathologischen CTG entschied man sich zur primären Sectio. Der APGAR-Score des Mädchens betrug 5/8/8. Die Nabelschnur-pH-Werte waren 7,26 bzw. 7,59. Nach der Verlegung auf die Intensivstation erfolgte ein Abdomen-CT. Diese bestätigte eine akute nekrotisierende Pankreatitis mit ausgeprägtem Aszites. Es wurde eine konservative Therapie begonnen, leider ohne Erfolg. Deshalb erfolgte die chirurgische Sanierung der Pankreas-Nekrosen. Nach langer Hospitalisation konnte die Patientin nach 2,5 Monaten nach Hause entlassen werden.

Diskussion: In einer Schwangerschaft kommt es im Fettstoffwechsel zu einer Erhöhung des Cholesterols und der Triglyceride, bedingt durch eine vermehrte Lebersynthese, was auf den erhöhten Östrogenspiegel zurückzuführen ist. Bei einem CS sollten der Triglyceridspiegel im Blut unter $500 \mathrm{mg} / \mathrm{dl}$ gehalten werden, um das Risiko einer AP zu reduzieren.

Schlussfolgerung: Niedergelassene Ärzte spielen eine wichtige Rolle hinsichtlich des Diagnostizierens der Erkrankung, der Veränderung des Lebensstils und ggf. der medikamentöse Intervention, um das Risiko einer AP zu verringern. 


\section{Introduction}

$\nabla$

Chylomicronemia syndrome is a rare familial genetic disorder characterized by an abnormal high level of triglycerides (>11.3 mmol/L) and a massive accumulation of chylomicrons. This condition can lead to the development of hepatosplenomegaly, occasionally lipemia retinalis, eruptive xanthoma or/and abdominal symptoms [1-2]. The incidence of this disorder is one in one million and it is caused by a gene mutation of an enzyme called lipoprotein lipase or apoprotein C-II. The deficiency of this enzyme, normally found in fat and muscle, determines the inability to reduce fatty acids [2-3]. In these cases one of the most feared potentially life threatening complications is a severe acute pancreatitis (AP). The incidence of AP is approximately $5 \%$ and the mortality, in severe cases, can reach 39\% [4-5]. During a pregnancy the woman undergoes profound and reversible anatomical and physiological change which also involves the lipid metabolism.

We present a very rare case of a pregnant woman with a severe AP affected by a chylomicronemia syndrome characterized by massive high levels of triglycerides in blood.

\section{Case}

A 38-year-old gravida 2, para 0 with an uneventful course of pregnancy and a history of a hypertriglyceridemia (HTG) of unknown origin for over 20 years was referred at 37 0/7 weeks of gestation to a nearby hospital with sudden and persistent abdominal pain. The chemical analysis excluded a HELLP syndrome but showed elevated pancreatic enzymes (lipase 1690 U/l, amylase $1533 \mathrm{U} / \mathrm{l}$ ) with significant HTG (triglyceride $155 \mathrm{mmol} / \mathrm{l}$ ). A diagnosis of acute pancreatitis was made and because of decreased coagulation values the patient was transferred to our hospital. At admission, a pathological fetal heart tracing associated with a breech presentation was detected and a caesarean delivery was performed immediately. The Apgar score of the female newborn was $5 / 8 / 8$ at 1,5 and 10 minutes, with a birth weight of $2720 \mathrm{~g}$. The $\mathrm{pH}$ from the umbilical cord were 7.26 (artery) and 7.59 (vein). Once transferred to our intensive care unit a computer tomography scan confirmed an onset of an AP associated with a massive abdominal fluid collection ( $\bullet$ Fig. 1). An acute pancreatitis secondary to HTG was considered. A conservative treatment with systemic antibiotics (imipenem), fluid replacement and parenteral nutrition was tried without success. For this reason a surgical debridement was performed and an infected necrosis of the pancreas was detected. The operation was performed via an upper midline access. Once localized the debridement was begun by a blunt dissection of the necrotic tissue. During the hospitalization the severe hypertriglyceridemia-induced pancreatitis was caused by a chylomicronemia syndrome (not known by the patient) associated by oestrogen exposure due to the pregnancy. After a long-lasting hospitalisation with cessation of oral intake and a continuous postoperative lavage the patient could be discharged home after 2.5 months in good general condition.

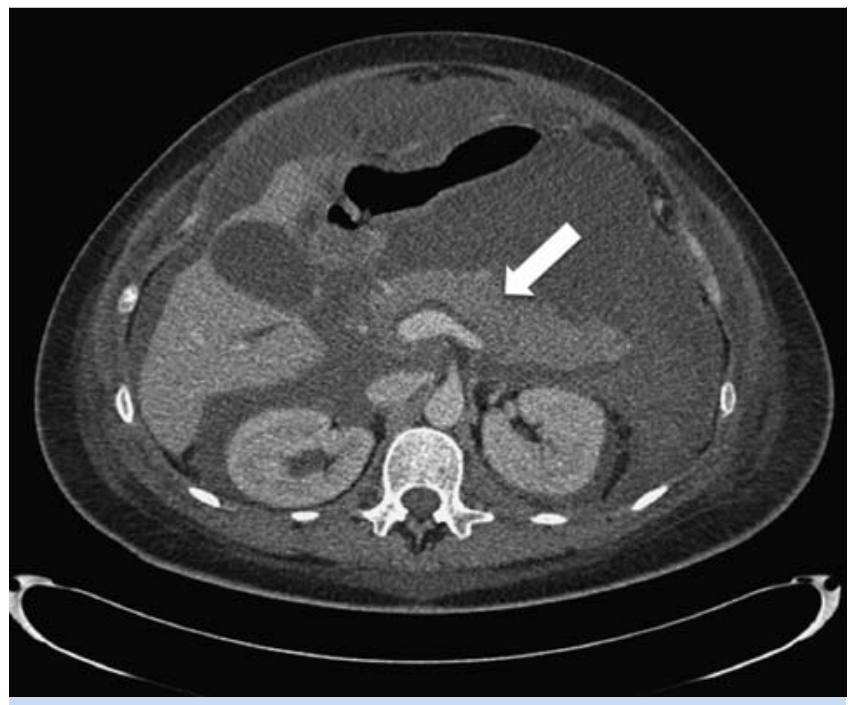

Fig. 1 Computer tomography scan showing the onset of acute pancreatitis.

\section{Discussion}

During pregnancy the lipid metabolism changes, characterized by an elevation of total plasma cholesterol and triglyceride levels. This is normally caused by an increased liver synthesis of triglycerides in response to elevated estrogen levels. These changes are important for the fetal-maternal needs. This high level of triglyceride concentration in the serum permits the mother to spare glucose for the fetus and allows, thanks to elevated LDL cholesterol levels, the placental stereodogenesis [6].

Acute pancreatitis is a life-threatening condition caused by different agents [7]. HTG, after alcohol and gallstones, is considered the third most common cause of AP ( Table 1 ). The identification of risk factors, like HTG, plays an important role in preventing AP. This disease has not yet not occurred in patients with triglyceride levels under $5.6 \mathrm{mmol} / \mathrm{L}$, but the risk of AP increases above this value and markedly over $11.3 \mathrm{mmol} / \mathrm{L}$ [8].

Pregnancy-induced HTG has been found to be responsible for up to $56 \%$ of cases of AP. In an uncomplicated pregnancy the serum triglycerides rarely exceed $3.3 \mathrm{mmol} / \mathrm{L}$ but if they do so, like in our case, the cause can be an unrecognized genetic disorder that elevates the concentration of triglycerides, predisposing the pregnant woman for AP [9].

Our patient had a history of undiagnosed cause of HTG for over 20 years. In this case the pregnancy had probably acted as triggering factor that determined an exacerbation of a pre-existing

Table 1 Common causes of acute pancreatitis.

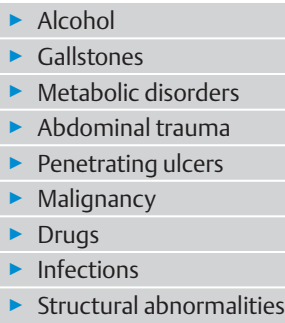


lipid abnormality determining a markedly elevation of triglycerides in blood up to $155 \mathrm{mmol} / \mathrm{L}$. The result was severe onset of AP with an increased risk of mortality for both mother and fetus. Preventive measures in patients affected by a chylomicronemia syndrome, especially before pregnancy occurs, play an important role to avoid an AP. When triglyceride levels are above $5.6 \mathrm{mmol} / \mathrm{L}$ a nonpharmacological treatment with weight loss, aerobic exercise, avoidance of sugars and strict glycemic control is considered sufficient to minimize the risk of AP $[10,11]$. On the contrary when the triglyceride level exceeds $11.3 \mathrm{mmol} / \mathrm{L}$, a pharmacological treatment for example with gemfibrozil must be started as soon as possible. This therapy is often required during the third trimester of pregnancy, a period during which the serum levels of triglycerides are normally at their highest $[12,13]$.

When an AP caused by HTG is detected, the therapy resembles that of pancreatitis of other origin, but differs in terms of the severity of the disease. In a mild AP, supportive care including pain control, intravenous fluids, correction of electrolyte and metabolic abnormalities is suggested. Intravenous insulin is a low-cost and effective good alternative treatment in HTG-induced pancreatitis during pregnancy [9]. This differs from cases of a severe AP where the mortality rate is around $39 \%$ and monitoring in an intensive care unit with support of renal, circulatory, pulmonary and hepatobiliary function with cessation of oral intake is strictly recommended. Fluid replacement and antibiotics like imipenem are usually administered to avoid a vascular leak syndrome in case of a necrotizing pancreatitis [14].

\section{Conclusion}

Early diagnosis of chylomicronemia syndrome is the key component to avoid severe complications and improve pregnancy outcome. Practitioners have an important role in evaluating chylomicronemic patients and implementing therapeutic lifestyle and pharmacologic interventions aimed to reduce the risk of AP.

\section{Conflict of Interest}

None.

\section{References}

1 Sarkany RP, Breathnach SM, Seymour CA et al. Metabolic and nutritional Disorders. In: Burns T, Breathnach S, Cox N, Griffiths C, eds. Rook's Textbook of Dermatology. 7th ed. Malden, Mass: Blackwell Publ. Inc.; 2004: 57-74

2 Leaf DA. Chylomicronemia and the chylomicronemia syndrome: a practical approach to management. Am J Med 2008; 121: 10-12

3 Custodis F, Laufs U. Hypertriglyceridämie: prognostische Bedeutung und Therapiemöglichkeiten. Dtsch Med Wochenschr 2011; 136: 1533-1542

4 Vege SS, Yadav D, Chari ST. Pancreatitis. In: Talley NJ, Locke GR, Saito YA, eds. GI Epidemiology. 1st ed. Malden, MA: Blackwell Publishing; 2007

5 Rath W, Friese K. Erkrankungen in der Schwangerschaft. Stuttgart: Thieme; 2005: 142-146

6 Napoli C, Palinski W. Maternal hypercholesterolemia during pregnancy influences the later development of atherosclerosis: clinical and pathogenic implications. Eur Heart J 2001; 22: 4

7 Aschoff AJ. Akute Pankreatitis. Fortschr Röntgenstr 2009; 181RK207_1. DOI: 10.1055/s-0029-1221036

8 Toskes PP. Hyperlipidemic pancreatitis. Gastroenterol Clin North Am 1990; 19: 783

9 Stimac D, Stimac T; Division of Gastroenterology, University Hospital Rijeka, Croatia. Acute pancreatitis during pregnancy. Eur J Gastroenterol Hepatol 2011; 23: 839-844

10 Ballantyne CM, Grundy SM, Oberman A et al. Hyperlipidemia: diagnostic and therapeutic perspectives. J Clin Endocrinol Metab 2000; 85: 2089

11 O'Brien T, Nguyen TT, Zimmerman BR. Hyperlipidemia and diabetes mellitus. Mayo Clin Proc 1998; 73: 969

12 Brunzell JD. Clinical practice. Hypertriglyceridemia. N Engl J Med 2007; 357: 1009

13 McBride PE. Triglycerides and risk for coronary heart disease. JAMA 2007; 298: 336

14 Johnson C, Charnley R, Rowlands B et al. UK guidelines for the management of acute pancreatitis. Gut 2005; 54 (Suppl. 3): iii1-iii9 